\title{
Impact of Price Framing on Consumers
}

\author{
Xinyu Weng
}

\author{
Minnehaha academy Minneapolis Minnesota 55406 United States \\ Corresponding author. Email: maxineweng03@gmail.com
}

\begin{abstract}
The manner, in which prices are presented to consumers, as well as their categories, has a great impact on consumers' behaviour. The main reason behind this phenomenon is that consumers tend to take 'shortcuts' when choosing between competing alternatives, be it products or services. As much as price framing is good for retailers and marketers, it has both positive and negative effects on consumers. When the strategy provides real value to consumers as perceived, then it is ethical. However, price framing at times could be misleading to consumers hence denying them value for their money. A number of scholars have analysed the effects of price framing from different perspectives. This paper provides a review analysis of various research works on price framing from the period in which the concept was officially included in academic literature. This review aims to find gaps in the literature concerning price framing and set a future agenda for research in this field. A systematic review approach was adopted for this study to ensure its purpose is achieved.
\end{abstract}

Keywords: Price framing, promotion, decision making, consumer behavior, price perception

\section{INTRODUCTION}

Marketing literature acknowledges price as one of the major influencers on consumers' decision-making. Buyers are likely influenced into behaving in a particular way depending on how price information is presented. The concept of presenting price information in different ways amounts to price framing. According to Manning and Sprott (2007), one of the most effective strategy to influence customer behavior is through price framing [15]. This is an indication that Price framing has an enormous impact on buyer decision-making process. The perceived gain or loss as a result of price framing makes people show varying risk behavior. A study of the literature reveals that Kahneman and Tversky popularized the concept of price framing through the famously known 'Prospect theory' (1979, 1984). The prospects theory gives an explanation of price framing on consumers' choices. The theory concluded that variations in price framing influence people's perceptions. For instance, "if a choice was framed as a gain, people became risk-averse and settled for less risky choice; however, framing the choice as a loss made people risk-seeking and go for a riskier choice." [22]. According to Chen et al. (1998), presenting price promotion in various ways has the same effect as tailoring purchase decisions, due to the fact that consumers receive the benefits either way [3].
A decision frame suffices when the decision-maker has their own perception of consumers' behavior, expected outcome of the action, and risks associated with a particular action. Choices can be framed in various ways by decision-makers with the objective of creating an appeal to consumers, and in turn, increase sales. Furthermore, shifts can occur at reference points and cause corresponding effects on consumer perception of a products' value and eventually change consumer preferences. Research on framing alludes that, ways in which a particular problem is framed influences human cognitive judgment. The purpose of this study is to have an analysis of literature and find the various effects of price framing on consumers.

\section{REVIEW OF APPROACH AND STRUCTURE}

The main objectives of the review were to find out the effects of price framing on consumers and also search for literature gaps in the field for future inferences. The time period within which this study was set to cover is between 2010 and 2021. However, a historical insight on the onset of the concept is also featured. The reason for this is that the concept of price framing was popularized and integrated into literature after 1980 by two scholars, Tversky and Kahneman. Apart from the time setting, inclusion and exclusion 
criteria and relevant keywords were chosen to meet the specific objectives of the review.

\subsection{Inclusion and exclusion criteria}

To meet the specific review objectives and have a comprehensive insight into the literature, a systematic approach was selected as recommended by [21]. The systematic review approach enables the researcher to identify, select and critically appraise research for purposes of answering a clearly established research question. Research articles for the literature are picked from multiple databases with defined criteria that meet the requirements of the study.

\subsection{Research paper and selection}

The only peer-reviewed articles were used in this paper due to their credibility and reliability in their presentation and research. The articles selected were all in the English language, something that could also amount to limitations for this review.

\section{THEORIES}

Theories and models provide information key to understanding fundamental concepts and behavior of associated phenomenon. Various theoretical models in marketing research have been developed to establish the relationship between price and consumer behavior. Literature on price framing gives two theories and two dominant models that explain the relationship between price and consumer choices. The two most renowned theories include the prospect theory by Kahneman and Tversky and the Transaction utility theory formulated by Thaler in 1985 [21]. According to this theory, price framing has a great influence on consumer choices. It concluded that the perception that people have as a result of price framing has a great impact on their decisions. "If a choice was framed as gain or loss affected people's actions," consumers opted for less risky alternatives when a choice was framed as a gain. On the other hand, consumers were inclined towards risky choices when the choice was framed as a loss. The second theory-Transaction Utility Theory, "posits that price framing affects the type of values people derive from purchase transactions." [21]. The transaction utility theory stipulates that two different types of values are at play: first among them is the acquisition value. Acquisition value is obtained when consumers receive similar product benefits despite paying less than a previous acquisition. However, this may be necessarily true because the price framing may make consumers feel like they are paying less for the current acquisition when in a real sense, they may be paying the actual price. The second value under The Transaction Utility Theory is the transaction value. The transaction value is associated with the psychological satisfaction that consumers get or enjoy as a result of price framing. The two dominating models include the Price-quality value model [13] and the means model [23].

\subsection{Price quality value model}

The price-quality value model is one of the most utilized models used to study the relationship between product price and resulting consumer perception. "The price-quality model describes the relationship between price, perceived quality, sacrifice, value and willingness to buy"[14]. According to this model, price acts as an external stimulus to customers while the sacrifice is the consumers take on paying the set price. Monroe and Krishna (1985) argued that end users have different price perceptions; while the objective price may seem high to some consumers, others hold the opposite view on the same [13]. The proponents of this model also allude that customers base their perception about the quality of a particular product on price. As such, high objective prices signify high-quality products while lower prices indicate low-quality products. Consequently, high prices amount to higher monetary sacrifice in product acquisition. However, the final determining factor in customers' willingness to purchases the product is the perceived value associated with the product at hand. Notably, perceived value is a result of the trade-off customers' perception of quality and the monetary sacrifice made for a successful transaction. In summary, the theory asserts that a consumer's decision to make a purchase rests on the products' perceived value. In addition, the willpower to purchase is increased with an increase in value.

\subsection{Means-end Model}

The means-end model portrays similar characteristics and assertions with the price-quality model. This model came later on in 1988 and was formulated by a scholar known as Zeithaml. It gives a comprehensive elaboration on the relationship that exists between objective prices, attached perceived product quality, and perceived product value. This model is defined as "one consisting of an interconnected set of cognitive elements that allow people to select objectives or activities that enable these people to achieve their desired goals."[14]. This model is of great benefit, especially to marketers, as it helps them have an understanding of the customers' cognitive orientation and product information retained at different stages of abstraction. This assertion is also held by Peter and Olson, who argued that there is certain product attributes brought about by price framing directly linked to functional and psychosocial, and individual perception of a product value [14]. According to Lee and Chen, "Zeithaml proposed a means-end model for consumers' perception of price, quality, and value, in which price is considered as an extrinsic cue of product 
attribute and price promotion can be a cue that signals quality change." [14]. This model agrees with the narrative of price promotion or rather price framing having a significant influence on end users' perception of a product. "The means model shows that price influences perceived monetary price; perceived monetary price influences perceived sacrifice and perceived quality." [14]. These factors, in turn, influence perceived value, hence influencing consumers' intention to purchase.

\section{PRICE FRAMING CONCEPTS AND KEY INFLUENCING FACTORS}

Price framing has been defined differently by a number of scholars in literature and yet point towards the same conclusions. Frisch (1993) defined it as "peoples' different reactions to the same decision problem owing to its representation in a different manner."[9]. The second definition was given by Tversky and Kahneman (1989). They defined framing as when the presentation of a statement with the same logical meaning about a similar occurrence or situation could make people make diverging decisions or actions [19]. Therefore, price framing was conceptualized by scholars as to the presentation of price in different ways but on equivalent terms such that it is interpreted differently by targeted consumers. This is achieved through framing prices or offers on purchase in different ways. Research from the literature seems to converge and agree with the notion that price framing is capable of influencing consumers' perceptions of attractive deals, transactional values, and the final acquisition decision [5, 10, 22]. According to Weinstein et al. (2018), the effectiveness of price framing depends on the level of effort used and the ability to integrate promotion benefits visible in the price information [22]. Generally, the availability of an offer or an apparent deal influences consumers' decision-making. According to DelVecchio (2005), consumers sum up as decision simplifiers [6]. When an offer is presented, it reduces the customer's cognitive effort in choosing a product hence playing a significant role in their decision making [6]. Various research sources indicate that the mere presence of a deal irrespective of there being actual price reduction increases the level of sales. However, as much as there are positive effects of price framing for both merchants and consumers, there is room for exploitation if the due diligence and ethical considerations are not part of the whole process

Various price framing strategies have been formulated and applied, as evident through research. Table 1 gives a summary of some of the price framing strategies used by retailers to influence consumers' decision-making process hence impacting their sales.

Table 1. Price framing strategies

\begin{tabular}{|c|c|c|c|c|}
\hline Type & Elaboration & Underlying theory & Application & Literature \\
\hline $\begin{array}{l}\text { Issuance of free } \\
\text { offers }\end{array}$ & $\begin{array}{l}\text { Retailers give an extra item for } \\
\text { free or just use the term free to } \\
\text { attract customers. }\end{array}$ & Regret theory & In retail shops & $\begin{array}{l}\text { Chen,Marmortsein,Tsi } \\
\text { ros,\&Rao (2012) [2] }\end{array}$ \\
\hline Drip pricing & $\begin{array}{l}\text { Part of the total price is withheld; } \\
\text { customers are only shown net } \\
\text { price while withholding other } \\
\text { charges, e.g., taxes that are } \\
\text { introduced later on during the } \\
\text { transaction process. }\end{array}$ & Adjustment theory & Air travel & $\begin{array}{l}\text { Tvesky } \\
\text { \&Kaneman(1974) } \\
{[19]}\end{array}$ \\
\hline $\begin{array}{l}\text { Rounding off } \\
\text { prices }\end{array}$ & $\begin{array}{l}\text { Prices are presented as rounded } \\
\text { off or odd figures }\end{array}$ & Regret theory & In retailing & $\begin{array}{l}\text { Choi \&Chatterjee } \\
(2014)[4]\end{array}$ \\
\hline Bundled offer & $\begin{array}{l}\text { Customers are offered red deals to } \\
\text { buy goods in bulk or bundles; they } \\
\text { are made to believe that they are } \\
\text { making savings by doing so. }\end{array}$ & Heuristic & Retail industry & $\begin{array}{l}\text { Manning } \\
\& \operatorname{Sprott}(2007)[15]\end{array}$ \\
\hline $\begin{array}{l}\text { Price presentation } \\
\text { order }\end{array}$ & $\begin{array}{l}\text { Prices are presented in a } \\
\text { descending or ascending order. }\end{array}$ & & Retail & $\begin{array}{l}\text { Suk } \\
\text { \&Lichtenstein(2012) } \\
{[18]}\end{array}$ \\
\hline $\begin{array}{l}\text { Time limiting } \\
\text { offer }\end{array}$ & $\begin{array}{l}\text { Offers are made available over a } \\
\text { limited period of time. }\end{array}$ & Gain and loss theory & Retail & $\begin{array}{l}\text { Dhar \& Nowlis (1999) } \\
\text { [7] }\end{array}$ \\
\hline Bait pricing & $\begin{array}{l}\text { Consumers are invited to make } \\
\text { purchases for the selected } \\
\text { discounted items while the motive } \\
\text { behind is to pull them towards } \\
\text { premium products. }\end{array}$ & $\begin{array}{l}\text { Commitment and } \\
\text { consistency }\end{array}$ & Retail & $\begin{array}{l}\text { Ellison \& } \\
\text { Elison(2009) [8] }\end{array}$ \\
\hline
\end{tabular}

Source: Ahmetoglu et al., 2014 [1] 


\section{EFFECTS OF PRICE FRAMING ON CONSUMERS}

Price framing is now regarded as a strategic marketing adjustable that has a great influence on end users' purchase tendencies and consequently boosts sales hence revenue [11]. The most common price framing strategies include price discounts; product promotion is used to appeal to consumers, boost store traffic for retailers and boost purchases. According to Kumar et al. (2012), there are two types of customers: price-conscious and non-price-conscious customers [12]. Of the two aforementioned customer categories, price-conscious customers are more vulnerable to promotion deals than those who are not. Therefore, price framing plays a major role in consumers' decisionmaking and could have significant effects on them both in the short term and the long run. On this particular subject matter, Research indicates that the effects of price framing on consumers' decision making are a combination of both positive and negative influences on consumers.

\subsection{Economic effects of price framing on consumers}

Lee and Chen (2018) describe the economic effects of price framing on consumers as monetary gains or benefits accrued as a result of the influence attached to the strategy [14]. According to the Scholars, a positive effect on customers, which, however, is non-monetary, is that it simplifies customer's decision-making process as less effort is imparted on the cognitive functions hence reducing time wastage [14]. On the other hand, the economic aspect of price promotion could result in time wastage when consumers get obsessed with price reductions and discounts. This is more visible with price-conscious customers who may waste a lot of time trying to find the best deal in the market. On the other hand, discounts and price reductions act as incentives that encourage customers to make purchases. The only negative assertion about this is that it encourages impulse buying just to not miss out on an offer [11].

\subsection{Informational effects of price framing on consumers}

Price framing, particularly discounting, creates a number of informational effects on the consumer. According to Raghubir et al. (2004), exposure to price framing creates contradicting perceptions and attitudes towards affected products in both positive and negative ways [17]. Customers tend to associate discounted products with low quality or are rather unpopular. This is more pronounced when consumers receive relatively high discounts on products that other merchants wouldn't offer under normal circumstances [14]. Therefore, it is sufficient to state that discounts could pass misleading information to customers who perceive discounted products as low-quality products.

\subsection{Affective effects of price framing on consumers}

Product promotion strategies, including price framing methods such as discounting and issuance of free offers, generate some amount of emotional impacts on consumers by arousing their emotions and feelings [17]. Customers are excited and have feelings of enjoyment whenever they feel to have gotten the best deal. According to the study by Piene et (2009), customers felt like smart shoppers when they paid a relatively lower price than perceived, and some developed a sense of accomplishment by just have been given an offer or a discount [16]. The reverse was also applicable: customers who missed out on a promotion or were limited to benefit from a promotion felt regretful, and some were even jealous for missing out on an offer. Therefore it can be concluded that price framing has both negative and positive influences on consumers' emotions.

\section{CONCLUSION}

Price framing is an effective marketing method for merchants as its one of the best strategies used to attract customers hence boosting sales. Marketing literature provides various price framing strategies used by retailers to attract customers, increase traffic flow in their stores and increase their sales. This includes discounts, free offers, and bundled offers, etc. However, as much as it has some benefits to consumers, including lessening the decision-making process, it could result in some negative effects such as excessive consumption and impulse buying. When the strategy provides real value to consumers as perceived, then it is ethical. However, price framing at times could be misleading to consumers hence denying them value for their money.

\section{AUTHORS' CONTRIBUTIONS}

The author contributed to the review design and implementation of the research through various academic sources, carrying of analysis, and writing the review paper.

\section{REFERENCES}

[1]Ahmetoglu, G., Furnham, A., \& Fagan, P. Pricing practices: A critical review of their effects on consumer perceptions and behaviour. Journal of Retailing and Consumer Services, 2014, 21(5), 696-707.

[2]Chen, H., Marmorstein, H., Tsiros, M., \& Rao, A.R. When more is less: The impact of base value neglect on consumer preferences for bonus packs 
over price discounts. Journal of Marketing, 2012, 76(4), 64-77.

[3]Chen, S. S., Monroe, K. B., \& Yung-Chein Lou. The effects of framing price promotion messages on consumers' perceptions and purchase intentions. Journal of Retailing, 1998, 74(3), 353-372. https://www.proquest.80599.net/scholarlyjournals/effects-framing-price-promotionmessages-on/docview/228603390/se2 ? accountid $=131239$

[4]Choi, J., Li, Y.J., Rangan, P., Chatterjee, P., \& Singh, S.N. The odd-ending price justification effect: The influence of price-endings on hedonic and utilitarian consumption. Journal of the Academy of Marketing Science, 2014, 42(5), 545-557. DOI: 10.1007/s11747-014-0369-6

[5]Choi, C., \& Mattila, A.S. The effects of promotion framing on consumers' price perceptions: The moderating role of a personal sense of power. Journal of Service Management. 2014.

[6]DelVecchio, D. Deal-prone consumers' response to promotion: The effects of relative and absolute promotion value. Psychology \& Marketing, 2005, 22(5), 373-391.

[7]Dhar, R., \& Nowlis, S.M. The effect of time pressure on consumer choice deferral. Journal of Consumer Research, 1999, 25(4), 369-384.

[8]Ellison, G., \& Ellison, S.F. Search, obfuscation, and price elasticities on the internet. Econometrica, 2009, 77(2), 427-452.

[9]Frisch, D. Reasons for framing effects. Organizational Behavior and Human Decision Processes, 1993, 54(3), 399-429.

[10]Goh, K.H., \& Bockstedt, J.C. The framing effects of multipart pricing on consumer purchasing behavior of customized information good bundles. Information Systems Research, 2013, 24(2), 334-351.06/obhd.1993.1017

[11]Konuk, F.A. The effects of price consciousness and sale proneness on purchase intention towards expiration date-based priced perishable foods. British Food Journal, 2015, 117(2), 793-804.

[12]Kukar-Kinney, M., Rigway, N.M. and Monroe, K.B. The role of price in the behavior and purchase decisions of compulsive buyers. Journal of Retailing, 2012, 88(1), 63-71.
[13]Krishnan, R. The effect of price on subjective product evaluations. Perceived Quality: How Consumers View Stores and merchandise, eds. Jacob Jacoby and Jerry C. Olson, Lexington, MA: DC Heath, 1985, 209-232.

[14]Lee, J.E., Chen-Yu, J.H. Effects of price discount on consumers' perceptions of savings, quality, and value for apparel products: mediating effect of price discount affect. International Journal of Interdisciplinary Research, 2018, 5(13).

[15]Manning, K.C., \& Sprott, D.E. Multiple unit price promotions and their effects on quantity purchase intentions. Journal of Retailing, 2007, 83(4), 411421.

[16]Peine, K., Heitmann, M., \& Herrmann, A. Getting a feel for price affect: A conceptual framework and empirical investigation of consumers' emotional responses to price information. Psychology \& Marketing, 2009, 26(1), 39-66.

[17]Raghubir, P., Inman, J.J., \& Grande, H. The three faces of consumer promotions. California Management Review, 2004, 46(4), 23-42.

[18]Suk, K., Lee, J., \& Lichtenstein, D.R. The influence of price presentation order on consumer choice. Journal of Marketing Research, 2012, 49(5), 708717.

[19]Tversky, A., \& Kahneman, D. Judgment under uncertainty: Heuristics and biases. Science, 1974, 185(4157), 1124-1131.

[20]Tranfield, D., Denyer, D., \& Smart, P. Towards a methodology for developing evidence-informed management knowledge by means of systematic review. British Journal of Management, 2003, 14(3), 207-222.

[21]Tripathi, A., \& Pandey, N. Price framing literature: Past, present, and future. The Marketing Review, 2017, 17(3), 307-336.

[22]Weisstein, F.L., Monroe, K.B., \& Kukar-Kinney, M. Effects of price framing on consumers' perceptions of online dynamic pricing practices. Journal of the Academy of Marketing Science, 2013, 41(5), 501-514.

[23]Zeithaml, V.A. Consumer perceptions of price, quality, and value: A means-end model and synthesis of evidence. Journal of Marketing, 1988, $52,2-22$. 